\title{
Measuring Efficiency of Using Currency Derivatives to Hedge Foreign Exchange Risk: A Study on Advanced Chemical Industries (ACl) in Bangladesh
}

\author{
Nusrat Jahan \\ Department of Business Adminstration, Uttara University, Uttara, Dhaka \\ Email address: \\ jn.nusrat@gmail.com
}

To cite this article:

Nusrat Jahan. Measuring Efficiency of Using Currency Derivatives to Hedge Foreign Exchange Risk: A Study on Advanced Chemical Industries (ACI) in Bangladesh. International Journal of Economics, Finance and Management Sciences. Vol. 4, No. 2, 2016 , pp. 57-66. doi: $10.11648 /$ j.ijefm.20160402.14

\begin{abstract}
Firms with greater growth opportunities and tighter financial constraints are more likely to use currency derivatives. This suggests that firms might use derivatives to reduce cash flow variation that might otherwise preclude firms from investing in valuable growth opportunities. Although in Bangladesh, the use of currency derivatives to hedge foreign exchange risk is not popular among the existing firms engaged in foreign exchange transactions, there are a few firms such as ACI \& General Motors etc with extensive foreign exchange-rate exposure and economies of scale in hedging activities are more likely to use currency derivatives. This is because, given the potential shifts in the supply of or demand for currency, firms and individuals who have assets denominated in foreign currencies can be affected favorably or unfavorably. These firms may want to alter their currency exposure in order to grab benefit or hedge risk from the expected movements of exchange rates. This study provides a detailed analysis along with a background on currency derivatives which are commonly used by some of large firms existing in Bangladesh in order to capitalize on or hedge against expected exchange rate exposures measured by these firms. In this paper, we have also divulged an analytical framework for measuring exchange rate exposures accelerating the use of currency derivatives in foreign exchange market of Bangladesh.
\end{abstract}

Keywords: Currency Derivatives, ACI Ltd., Exposures, Hedging, Speculation

\section{Introduction}

A currency derivative is a contract whose price is partially derived from the value of the underlying currency that it represents. Some individuals and financial firms take positions in currency derivatives to speculate on future exchange rate movements. Large corporations such as ACI or General Motors in Bangladesh commonly take positions in currency derivatives to hedge their exposure to exchange rate risk. Their managers must understand how these derivatives can be used to achieve corporate goals. Theories of optimal hedging demonstrate that the imperfections in capital market (DSE \& CSE) of Bangladesh create incentives for firms to use derivative instruments in foreign exchange transactions. While these imperfections might be necessary for optimal derivatives use, they are not sufficient conditions. We argue that given these incentives, a firm's ultimate decision to use derivatives also depends on the level of its exposure to foreign exchange-rate risk. In addition, a firm's choice to use currency derivatives depends on the costs of managing foreign exchange-rate risk. Therefore, it is reasonable to expect a connection between exchange rate exposures and firm value. If the Bangladeshi firms are highly exposed to exchange rate fluctuations, it can consider techniques (use of currency derivatives) to reduce its exposure. Moreover, these firms must estimate its exposures to exchange rate movements prior to the decision on using currency derivatives to hedge exchange rate exposures.

\section{Literature Review}

As the use of currency derivative is a new concept as well as very insignificant among the firms existing in Bangladesh, there is no prior research on measuring the efficiency of using currency derivatives to hedge exchange rate exposures in foreign exchange market of Bangladesh. Exchange-rate movements affect expected future cash flows, and therefore their returns, by changing the home currency value of foreign 
revenues (costs) and the terms of competition for large multinationals and small exporters (importers). In light of this, it is surprising that previous research in this area [Jorion (1990), Amihud (1993) and Bodnar and Gentry (1993)] finds that no U. S. multinationals, exporters, or manufacturing industries are significantly affected by exchange-rate movements.

Smith and Stulz (1985), Bessembinder (1991), Froot, Scharfstein, and Stein (1993), and Leland (1998) suggest that the use of derivatives for risk management purposes adds value to a firm by reducing expected taxes or financial distress costs, by mitigating underinvestment or by allowing a firm to increase its debt capacity and take advantage of debt tax-shields without an increase in risk. On the other hand, managerial risk aversion motives may lead managers to use derivatives to engage in risk management activities to protect themselves and not necessarily to benefit shareholders (Stulz (1984) and Smith and Stulz (1985)). Finally, Geczy, Minton, and Schrand (2007) find that firms may also use derivatives to speculate, an activity which we should again not expect to benefit investors on average.

Specifically, Allayannis and Weston (2001) find that the use of foreign currency derivatives is positively associated with firm value in a large sample of U. S. nonfinancial firms with exposure to exchange rates, Mackay and Moeller (2007) find a similar effect for the use of derivatives in a sample of oil refiners and Bartram, Brown, and Conrad (2011) find a positive valuation effect in a large sample of nonfinancial firms from 47 countries. However, Guay and Kothari (2003) argue that based on the magnitudes of the notional amounts of the derivatives used by U. S. firms, the value implications of their use should be modest. Further, Jin and Jorion (2006) find no value impact for the use of derivatives in a sample of oil and gas producers.

Empirical examination of hedging theories has been hampered by the general unavailability of data on hedging activities. Until the beginning of the 1990s, a firm's exact position in derivatives was privately held information, and was considered a very important component of strategic competitiveness. It is only recently that corporations have been required to disclose in footnotes in their annual reports, the notional amount of derivatives they are using.

Recently, studies have focused on the type of hedging (commodity, interest rate, or currency), recognizing that different factors can be important for each type of hedging. In particular, Geczy, Minton, and Schrand (1997) examine currency hedging activities for a sample of Fortune 500 firms. They find that firms' use of currency derivatives is positively related to the amount of R\&D expenditures, which is consistent with the use of hedging as a mitigating factor in potential underinvestment problems (e.g., Froot, Scharfstein, and Stein 1993); size which is consistent with fixed-costs of hedging explanations; and exposure factors (foreign income and trade). Tufano (1996) examines commodity hedging activities in the gold mining industry. He finds that firms' use of commodity derivatives is negatively related to the number of options their managers and directors hold, and positively related to the value of their stock holdings, evidence consistent with theories of managerial risk aversion (e.g., Stulz, 1984). Haushalter (1997) examines the hedging activities of oil and gas producers.

All of the studies cited above have examined which factors could be associated with the probability that a firm hedges. With the exception of Tufano (1996) and Haushalter (1997), who also examine the level of hedging in a particular industry (gold, and oil and gas respectively), no other study in the general derivatives area has looked for the factors that are associated with the extent of hedging.

\section{Objectives}

The broad objective of this study is to determine the exposures of using several types of currencies in foreign exchange market and how a typical corporation in Bangladesh can hedge the fluctuation of exchange rates in foreign exchange market.

The specific objectives of this study are:

- To discuss how a typical firm in Bangladesh can measure the expected exposures in foreign exchange transactions.

- To explain how forward contracts are used by a Bangladeshi firm to hedge based on anticipated exchange rate movements,

- To describe how currency futures contracts are used to speculate or hedge based on anticipated exchange rate movements,

- To explain how currency options contracts are used by a Bangladeshi firm to speculate or hedge based on anticipated exchange rate movements, and

- To explain how currency Straddles (combination of Call options \& Put options) contracts are used by a Bangladeshi firm to speculate or hedge based on anticipated exchange rate movements in foreign exchange market in Bangladesh.

\section{Methodology}

The study has been divided into two parts where first part deals with the methods used by Bangladeshi firms engaged in Hedging to measure the exposures to exchange rate fluctuation and the second part deals with the extent of using currency derivatives to hedge the exposures to exchange rate fluctuations. The complete methodology for preparing this paper is revealed below:

\subsection{Research Type}

This is a descriptive research which is relevant to an inquisitive study as it requires some analysis on the foreign exchange operations conducted by the local companies existing in Bangladesh such as ACI or General Motors. It also includes the detailed analysis of methods used by ACI Ltd, a local company based on Bangladesh, to measure its foreign exchange exposures related the operations in foreign exchange market of Bangladesh. In final part, this paper 
reveals the process of using currency derivatives to hedge against the foreign exchange risk measured by ACI Corporation in terms of its net cash inflows denominated in different currencies.

\subsection{Types of Data}

Preparing this study requires the use of only secondary data related to firm's value, correlations among the exchange rates and the assistance from various books and articles etc as shown below:

Annual Reports of ACI (Advanced Chemical Industries Ltd.) from 2005 to 2010 .

WEB sites of ACI Ltd.

Annually published materials related to currency hedging throughout the global foreign exchange market.

Corporate publications such as BEAMS - a quarterly newsletter that communicate stories about the various activities of the diverse business and functions to promote awareness among the ACI family members.

Another Corporate Publication such as Synergy - that aims towards enriching several types of practical knowledge to enhance employee motivation and work culture in ACI Corporation.

WEB site of Bangladesh Bank.

\subsection{Data Analysis Tools}

The following mathematical models are used to analyze the exchange rate exposures associated with the local companies such as ACI Ltd or General Motors Ltd etc engaged in currency hedging through using several currency derivative contracts as revealed below:

Application of Portfolio Standard Deviation Model for calculating the exchange rate exposures associated with net inflows denominated with four different currencies for ACI Corporation.

Calculation of Profit / Loss for both the Buyer (ACI Ltd) and the Seller (SCBL) of options contract used by ACI to hedge or speculate against exchange rate exposures of foreign exchange market in Bangladesh.

Calculation of Profit / Loss for both the Buyer (either ACI Ltd or SCBL) and the Seller (either SCBL or ACI Ltd) of Currency Straddles contract used by ACI to hedge or speculate against exchange rate exposures of foreign exchange market in Bangladesh.

Application of Worksheet Model for calculating the value of foreign currency (say for "Euro" in this paper) at option expiration in case of either Long or short currency straddles used by firms in Bangladesh to hedge against foreign exchange exposures.

\section{Measuring Exposures to Exchange Rate Movements}

The value of a firm's future contractual transactions in foreign currencies is affected by exchange rate movements. The sensitivity of the firm's contractual transactions in foreign currencies to exchange rate movements is referred to as transaction exposure. Transaction exposure can have a substantial impact on a firm's value. It is not unusual for a currency to change by as much as 10 percent in a given year. If an exporter denominates its exports in a foreign currency, a 10 percent decline in that currency will reduce the dollar value of its receivables by 10 percent. This effect could possibly eliminate any profits from exporting. To assess transaction exposure, a renowned firm named ACI based on Bangladesh, follows a specific methods consisting of following estimations

(1) At first, ACI must estimate its net cash flows in each currency and

(2) It also measures the potential impact of the currency exposure as illustrated below:-

ACI Corporation, a Bangladeshi firm expects to receive substantial payments denominated in four different types of currencies as shown below along with other information:

Table 1. Substantial inflows and outflows denominated in four different currencies for ACI.

\begin{tabular}{llllll}
\hline Types of Currencies & Inflow of currencies & Outflow of currencies & Std. Deviation & Expected Exchange rate & value of net Inflow \\
\hline British Pound & $£ 17,000,000$ & $£ 11,000,000$ & 0.05 & BDT 1.50 & ---- \\
Canadian BDT & C $12,000,000$ & C $5,000,000$ & 0.09 & BDT 0.80 & - \\
Japanese Yen & Y $20,000,000$ & Y $12,000,000$ & 0.07 & BDT 0.15 & --- \\
Euro & $€ 90,000,000$ & $€ 25,000,000$ & 0.08 & BDT 0.25 & --- \\
\hline
\end{tabular}

Source: Annual reports of ACI

Table 2. Value of net inflow denominated in domestic currency (BDT) \& their corresponding weights for ACI Corporation in Bangladesh.

\begin{tabular}{|c|c|c|c|c|c|c|}
\hline $\begin{array}{l}\text { Types of } \\
\text { Currencies (1) } \\
\end{array}$ & $\begin{array}{l}\text { Inflow of currencies } \\
(2)\end{array}$ & $\begin{array}{l}\text { Outflow of } \\
\text { currencies (3) }\end{array}$ & $\begin{array}{l}\text { Net inflow }(4)= \\
(2)-(3)\end{array}$ & $\begin{array}{l}\text { Expected } \\
\text { Exchange rate (5) } \\
\end{array}$ & $\begin{array}{l}\text { value of net Inflow } \\
(6)=(4) *(5)\end{array}$ & $\begin{array}{l}\text { Weights }(7)= \\
6 / \text { total }\end{array}$ \\
\hline British Pound & $£ 17,000,000$ & $£ 11,000,000$ & $£ 6,000,000$ & BDT1.50 & BDT $9,000,000$ & 0.281 \\
\hline Canadian BDT & C\$ $12,000,000$ & $\mathrm{C} \$ 5,000,000$ & $\mathrm{C} \$ 7,000,000$ & BDT0.80 & BDT $5,600,000$ & 0.175 \\
\hline Japanese Yen & Y $20,000,000$ & Y $12,000,000$ & Y 8,000,000 & BDT0.15 & BDT $1,200,000$ & 0.037 \\
\hline Euro & $€ 90,000,000$ & $€ 25,000,000$ & $€ 65,000,000$ & BDT0.25 & BDT $16,250,000$ & 0.507 \\
\hline total & & & & & BDT $32,054,000$ & 1.000 \\
\hline
\end{tabular}

Source: Analysis report of Treasury department in ACI 
The calculated correlation between British Pound and Canadian Dollar is 0.69 , the correlation between British Pound and Japanese Yen is 0.95 , the correlation between British Pound and Euro is 0.56 , the correlation between Canadian Dollar and Japanese Yen is 0.26. All other correlations are 0 .

On the basis of above information, if we want to assess transaction exposure, we need to calculate the net cash flows along with their corresponding weights of each currency as shown below:

Secondly, we have to assess the potential impact of the currency exposure by arranging the correlation table on the basis of above information regarding correlation between the currencies as depicted below:

Table 3. Correlation Table.

\begin{tabular}{lllll}
\hline & British Pound & Canadian \$ & Japanese Yen & Euro \\
\hline British Pound & 1 & 0.69 & 0.95 & 0.56 \\
Canadian \$ & 0.69 & 1 & 0.26 & 0 \\
Japanese Yen & 0.95 & 0.26 & 1 & 0 \\
Euro & 0.56 & 0 & 0 & 1 \\
\hline
\end{tabular}

Source: Analysis report of Treasury department in ACI

The dollar net cash flows of ACI are generated from a portfolio of currencies. The exposure of the portfolio of currencies can be measured by the standard deviation of the portfolio, which indicates how the portfolio's value may deviate from what is expected. After that the risk (as measured by the standard deviation of monthly percentage changes) of a two-currency portfolio $\left(\sigma_{\mathrm{p}}\right)$ can be estimated as follows:

$$
\sigma=\sqrt{ }\left(\mathrm{W}_{\mathrm{x}} \sigma_{\mathrm{x}}\right)^{2}+\left(\mathrm{W}_{\mathrm{y}} \sigma_{\mathrm{y}}\right)^{2}+2 \mathrm{~W}_{\mathrm{x}} \mathrm{W}_{\mathrm{y}} \sigma_{\mathrm{x}} \sigma_{\mathrm{y}} \mathrm{CORR}_{\mathrm{xy}}
$$

Here,

$\mathrm{W}_{\mathrm{X}}=$ proportion of total portfolio value that is in currency $\mathrm{X}$

$\mathrm{W}_{\mathrm{Y}}=$ proportion of total portfolio value that is in currency $\mathrm{Y}$

$\sigma_{X}=$ standard deviation of monthly percentage changes in currency $\mathrm{X}$

$\sigma_{Y}=$ standard deviation of monthly percentage changes in currency $\mathrm{Y}$

$\mathrm{CORR}_{\mathrm{XY}}=$ correlation coefficient of monthly percentage changes between currencies

$\mathrm{X}$ and $\mathrm{Y}$

The equation shows that ACI's exposure to multiple currencies is influenced by the variability of each currency and the correlation of movements between the currencies. The volatility of a currency portfolio is positively related to a currency's volatility and positively related to the correlation between currencies. Each component in the equation that affects a currency portfolio's risk can be measured by using a series of monthly percentage changes in each currency. So the estimation of risk (as measured by the standard deviation of monthly percentage changes) of a four currency portfolio $\left(\sigma_{\mathrm{p}}\right)$ can be estimated as follows:

$$
\sigma_{\mathrm{p}}^{2}=(.05 \times 0.281)^{2}+(0.09 \times 0.175)^{2}+(0.07 \times 0.037)^{2}+
$$
$(0.08 \times 0.507)^{2}$

$$
\begin{aligned}
& +2 \times 0.69 x .05 x .09 x .281 x .175 \\
& +2 x 0.95 x .05 x .07 x .281 x .037 \\
& +2 x 0.56 x .05 x .08 x .281 \times .507 \\
& +2 x 0.26 x .09 x .07 x .175 x .037 \\
& +2 x 0.0 x .09 x .08 x .175 x .507 \\
& +2 x 0.0 x .07 x .08 x .037 x .507
\end{aligned}
$$

So, $\sigma_{\mathrm{p}}=0.0538$ or $5.38 \%$ (approximately)

It means that the exposure of ACI Incorporation of Bangladesh for deriving substantial payments denominated in four different types of currencies is estimated about $5.038 \%$. More precisely, a corporation is exposed to risk estimated as $5.038 \%$ on the portfolio consisting of four different types of currencies.

\section{Hedging Exposures with Currency Forward Contract in Foreign Exchange Market}

The forward market facilitates the trading of forward contracts on currencies. A forward contract is an agreement between a corporation and a commercial bank to exchange a specified amount of a currency at a specified exchange rate (called the forward rate) on a specified date in the future. ${ }^{1}$ When multinational corporations (MNCs) or any Local Corporation Such As ACI based on Bangladesh anticipate a future need for or future receipt of a foreign currency, they can set up forward contracts to lock in the rate at which they can purchase or sell a particular foreign currency. Virtually all large MNCs use forward contracts. Some MNCs have forward contracts outstanding worth more than BDT100 million to hedge various positions.

MNCs use forward contracts to hedge their imports. They can lock in the rate at which they obtain a currency needed to purchase imports.

According to the Report of Treasury department in ACI, Inc., a local firm based in Bangladesh that will need $1,000,000$ Singapore dollars in 90 days to purchase Singapore imports. It can buy Singapore dollars for immediate delivery at the spot rate of BDT 0.50 per Singapore dollar (S\$). At this spot rate, the firm would need BDT 500,000 (computed as $\$ \$ 1,000,000 \times$ BDT.50 per Singapore dollar). However, it does not have the funds right now to exchange for Singapore dollars. It could wait 90 days and then exchange U. S. dollars for Singapore dollars at the spot rate existing at that time. But ACI does not know what the spot rate will be at that time. If the rate rises to BDT.60 by then, ACI will need BDT 600,000 (computed as S\$1,000,000 x BDT.60 per Singapore dollar), an additional

1 Stulz, R., 1984, IOptimal hedging policies," Journal of Financial and Quantitative Analysis 19, June. 
outlay of BDT 100,000 due to the appreciation of the Singapore dollar. To avoid exposure to exchange rate risk, ACI can lock in the rate it will pay for Singapore dollars 90 days from now without having to exchange Bangladeshi Taka for Singapore dollars immediately. Specifically, ACI can negotiate a forward contract with a bank to purchase $\mathrm{S} \$ 1,000,000$ for 90 days forward.

The difference between the forward rate $(F)$ and the spot rate $(S)$ at a given point in time is measured by the premium:

$\mathrm{F}=\mathrm{S}(1+\mathrm{P})$

Accordingly, If the euro's spot rate is BDT1.03, and its one-year forward rate has a forward premium of 2 percent, the one-year forward rate is:

$\mathrm{F}=\mathrm{S}(1+\mathrm{P})=$ BDT $1.03(1+0.02)=$ BDT 1.056

Given quotations for the spot rate and the forward rate at a given point in time, the premium can be determined by rearranging the above equation:

$$
\begin{aligned}
& \mathrm{F}=\mathrm{S}(1+\mathrm{P}) \\
& \mathrm{F} / \mathrm{S}=1+\mathrm{p} \\
& (\mathrm{F} / \mathrm{S})-1=\mathrm{P}
\end{aligned}
$$

In some situations, a firm may prefer to assess the premium or discount on an unannualized basis. In this case, it would not include the fraction that represents the number of periods per year in the formula.

\subsection{Hedging Exposures with Currency Future Contract in FX Market}

Currency futures contracts are contracts specifying a standard volume of a particular currency to be exchanged on a specific settlement date. Thus, currency futures contracts are similar to forward contracts in terms of their obligation, but differ from forward contracts in the way they are traded. ${ }^{2}$ They are commonly used by some Bangladeshi firms to hedge their foreign currency positions. In addition, they are traded by speculators (often the treasury managers of firm in case of Bangladesh) who hope to capitalize on their expectations of exchange rate movements. A buyer of a currency futures contract locks in the exchange rate to be paid for a foreign currency at a future point in time. Alternatively, a seller of a currency futures contract locks in the exchange rate at which a foreign currency can be exchanged for the home currency. In the United States, currency futures contracts are purchased to lock in the amount of dollars needed to obtain a specified amount of a particular foreign currency; they are sold to lock in the amount of dollars to be received from selling a specified amount of a particular foreign currency.

The purchase of futures contracts locks in the price at which a firm can purchase a currency. To illustrate this issue, we have to consider the following issue:

ACI Co. orders Canadian goods and upon delivery will need to send C\$500,000 to the Canadian exporter. Thus, ACI purchases Canadian dollar futures contracts today, thereby locking in the price to be paid for Canadian dollars at a

2 Jorion, P., 1990, "The Exchange Rate Exposure of U. S. Multinationals," Journal of Business (July), 331-345 future settlement date. By holding futures contracts, ACI does not have to worry about changes in the spot rate of the Canadian dollar over time.

\subsection{Hedging Exposures with Currency Options Contract in FX Market}

Currency options provide the right to purchase or sell currencies at specified prices. They are available for many currencies, including the Australian dollar, British pound, Brazilian real, Canadian dollar, euro, Japanese yen, Mexican peso, New Zealand dollar, Russian ruble, South African rand, and Swiss franc.

\section{Hedging with currency Call Options:}

A currency call option grants the right to buy a specific currency at a designated price within a specific period of time. The price at which the owner is allowed to buy that currency is known as the exercise price or strike price, and there are monthly expiration dates for each option. ${ }^{3}$ Call options are desirable when one wishes to lock in a maximum price to be paid for a currency in the future. If the spot rate of the currency rises above the strike price, owners of call options can "exercise" their options by purchasing the currency at the strike price, which will be cheaper than the prevailing spot rate. This strategy is somewhat similar to that used by purchasers of futures contracts, but the futures contracts require an obligation, while the currency option does not. The owner can choose to let the option expire on the expiration date without ever exercising it. Owners of expired call options will have lost the premium they initially paid, but that is the most they can lose.

A currency call option is said to be in the money when the present exchange rate exceeds the strike price, at the money when the present exchange rate equals the strike price, and out of the money when the present exchange rate is less than the strike price. For a given currency and expiration date, an in-the-money call option will require a higher premium than options that are at the money or out of the money.

According to the Report of Treasury department in ACI a local company based in Bangladesh that has bid on a project sponsored by the Canadian government. If the bid is accepted, ACI will need approximately C $\$ 500,000$ to purchase Canadian materials and services. However, ACI will not know whether the bid is accepted until 3 months from now. In this case, it can purchase call options with a 3-month expiration date. Ten call option contracts will cover the entire amount of potential exposure. If the bid is accepted, ACI can use the options to purchase the Canadian dollars needed. If the Canadian dollar has depreciated over time, ACI will likely let the options expire. Assume that the exercise price on Canadian dollars is BDT.70 and the call option premium is BDT.02 per unit. ACI will pay BDT 1,000 per option (since there are 50,000 units per Canadian dollar option), or BDT 10,000 for the 10 option contracts. With the options, the maximum amount necessary to purchase the $\mathrm{C} \$ 500,000$ is BDT 350,000 (computed as BDT

3 Block, S. and Gallagher, T., 1986, \The use of interest rate futures and options by corporate financial managers" Financial Management, Autumn. 
0.70 per Canadian dollar x C\$500,000). The amount of Bangladeshi Taka needed would be less if the Canadian dollar's spot rate were below the exercise price at the time the Canadian dollars were purchased.

\section{Speculating with currency Call Options:}

Individuals may speculate in the currency options market based on their expectation of the future movements in a particular currency. Speculators who expect that a foreign currency will appreciate can purchase call options on that currency. Once the spot rate of that currency appreciates, the speculators can exercise their options by purchasing that currency at the strike price and then sell the currency at the prevailing spot rate.

Just as with currency futures, for every buyer of a currency call option there must be a seller. A seller (sometimes called a writer) of a call option is obligated to sell a specified currency at a specified price (the strike price) up to a specified expiration date. ${ }^{4}$ Speculators may sometimes want to sell a currency call option on a currency that they expect will depreciate in the future. The only way a currency call option will be exercised is if the spot rate is higher than the strike price. Thus, a seller of a currency call option will receive the premium when the option is purchased and can keep the entire amount if the option is not exercised. When it appears that an option will be exercised, there will still be sellers of options. However, such options will sell for high premiums due to the high risk that the option will be exercised at some point. To illustrate the situation, we may consider the following issue:

ACI Corporation based in Bangladesh is a speculator who buys a British pound call option with a strike price of BDT 1.40 and a December settlement date. The current spot price as of that date is about BDT 1.39. ACI pays a premium of BDT.012 per unit for the call option. Assume there are no brokerage fees. Just before the expiration date, the spot rate of the British pound reaches BDT 1.41. At this time, ACI exercises the call option and then immediately sells the pounds at the spot rate to a bank. To determine ACI's profit or loss, the computations are given below. Assume one option contract specifies 31,250 units.

Table 4. Calculation of profit / loss for the Buyer (ACI) of Call Options Contract.

\begin{tabular}{|c|c|c|}
\hline Descriptions & per unit & per contract \\
\hline Selling price of $£$ & BDT1.41 & $\begin{array}{l}\text { BDT44,063 (BDT1.41 x 31,250 } \\
\text { units) }\end{array}$ \\
\hline (-) Purchase price of $£$ & -1.40 & $-43,750$ (BDT1.40 x 31,250 units) \\
\hline $\begin{array}{l}\text { (-)Premium paid for } \\
\text { option }\end{array}$ & -0.012 & -375 (BDT.012 x 31,250 units) \\
\hline$=$ Net profit & -BDT0.002 & -BDT62 (-BDT.002x 31,250 units) \\
\hline
\end{tabular}

Source: Analysis report of Treasury department in ACI

Assume that SCBL (Standard Chartered Bank Ltd) of Bangladesh was the seller of the call option purchased by ACI. Also assume that SCBL would purchase British pounds

4 Haushalter, D., $1997 \backslash$ The role of corporate hedging: Evidence from oil and gas producers" Working Paper, Purdue University, West Lafayette, IN. only if and when the option was exercised, at which time she must provide the pounds at the exercise price of BDT1.40. Using the information in this example, SCBL's net profit from selling the call option is derived here:

Table 5. Calculation of profit / loss for the Seller (SCBL) of Call Options Contract.

\begin{tabular}{|c|c|c|}
\hline Descriptions & per unit & per contract \\
\hline Selling price of $£$ & BDT1.40 & 43,750 (BDT1.40 x 31,250 units) \\
\hline (-) Purchase price of $£$ & -1.41 & $\begin{array}{l}\text {-BDT44,063 (BDT1.41 x 31,250 } \\
\text { units) }\end{array}$ \\
\hline $\begin{array}{l}(+) \text { Premium received } \\
\text { for option }\end{array}$ & +0.012 & -375 (BDT.012 x 31,250 units) \\
\hline$=$ Net profit & +BDT0.002 & +BDT62 (-BDT.002x 31,250 units) \\
\hline
\end{tabular}

Source: Report of Treasury department in ACI

\section{Hedging with currency put options:}

The owner of a currency put option receives the right to sell a currency at a specified price (the strike price) within a specified period of time. As with currency call options, the owner of a put option is not obligated to exercise the option. Therefore, the maximum potential loss to the owner of the put option is the price (or premium) paid for the option contract.

A currency put option is said to be in the money when the present exchange rate (spot rate) is less than the strike price, at the money when the present exchange rate equals the strike price, and out of the money when the present exchange rate exceeds the strike price. ${ }^{5}$ For a given currency and expiration date, an in-the-money put option will require a higher premium than options that are at the money or out of the money. Corporations with open positions in foreign currencies can use currency put options in some cases to cover these positions.

\section{$I V$. Speculating with currency put options:}

Individuals or Corporations may speculate with currency put options based on their expectations of the future movements in a particular currency. ${ }^{6}$ For example, speculators of Bangladesh say for ACI Corporation that expects that the British pound will depreciate can purchase British pound put options, which will entitle them to sell British pounds at a specified strike price. If the pound's spot rate depreciates as expected, the speculators can then purchase pounds at the spot rate and exercise their put options by selling these pounds at the strike price. The net profit to a speculator from trading put options on a currency is based on a comparison of the exercise price at which the currency can be sold versus the purchase price of the currency and the premium paid for the put option. To illustrate the situation, we may consider the following issue:

A put option contract on British pounds specifies the following information:

5 Simkins, B., and Laux, P., 1997, Derivatives use and the exchange rate risk of investing in large U. S. Corporations," Working Paper, Case Western Reserve University.

6 Bodnar, G., Hayt, G., Marston, R., and Smithson, W., 1995, IWharton survey of derivatives usage by U. S. non-financial firms." Financial Management, 24, Summer 
- Put option premium on British pound $(£)=$ BDT 0.04 per unit.

- Strike price $=$ BDT1.40.

- One option contract represents $£ 31,250$.

ACI that had purchased this put option decided to exercise the option shortly before the expiration date, when the spot rate of the pound was BDT1.30. The speculator purchased the pounds in the spot market at that time. Given this information, the net profit to the purchaser of the put option is calculated as follows:

Table 6. Calculation of profit / loss for ACI Corporation (Buyer of Put Options) Contract.

\begin{tabular}{lll}
\hline Descriptions & per unit & per contract \\
\hline Selling price of $£$ & BDT1.40 & 43,750 (BDT1.40 × 31,250 units) \\
(-)Purchase price of $£$ & -1.30 & -BDT40,625 (BDT1.30 x 31,250 \\
(-)Premium paid & -0.04 & units) \\
$=$ Net profit & BDT+.06 & +BDT1875 (-BDT.06 31,250 units) \\
\hline
\end{tabular}

Source: Report of Treasury department in ACI

On the contrary, SCBL (Standard Chartered Bank Ltd) of Bangladesh, the seller of the put option, sold the pounds received immediately after the option was exercised; the net profit to the seller of the put option is calculated as follows:

Table 7. Calculation of profit / loss for SCBL (Seller of Put Options Contract).

\begin{tabular}{|c|c|c|}
\hline Descriptions & per unit & per contract \\
\hline Selling price of $£$ & BDT1.30 & $\begin{array}{l}\text { BDT40,625 (BDT1.30 x 31,250 } \\
\text { units) }\end{array}$ \\
\hline (-) Purchase price of $£$ & 1.40 & $-43,750$ (BDT1.40 x 31,250 units) \\
\hline$(+)$ Premium received & +0.04 & +1250 (BDT.04 x 31,250 units) \\
\hline$=$ Net profit & -BDT.06 & -BDT1875 (-BDT.06x 31,250 units) \\
\hline
\end{tabular}

Source: Report of Treasury department in ACI

The seller of the put options could simply refrain from selling the pounds (after being forced to buy them at BDT1.40 per pound) until the spot rate of the pound rises. However, there is no guarantee that the pound will reverse its direction and begin to appreciate. The seller's net loss could potentially be greater if the pound's spot rate continued to fall, unless the pounds were sold immediately.

It's inferred from the above discussion that the options contracts are used for both hedging and speculative purposes in case of international foreign currency market. Therefore, the following table shows the at a glance effect of Spot rate as well as strike rate of several types of currencies traded in international foreign exchange market as depicted below:

Table 8. Effects of Strike rate and Spot rate in FX currency market.

\begin{tabular}{lll}
\hline Parties of options contract & Strike price/rate & Spot price/rate \\
\hline Buyer of call options & Purchase price/rate & Selling price/rate \\
Seller of call options & Selling price/rate & Purchase price/rate \\
Buyer of Put options & Selling price/rate & Purchase price/rate \\
Seller of Put options & Purchase price/rate & Selling price/rate \\
\hline
\end{tabular}

Source: Report of Treasury department in ACI

\subsection{Hedging Exposures with Currency Options Combinations}

A currency option combination uses simultaneously call and put option positions to construct a unique position to suit the hedger's or speculator's needs. A currency option combination may include both long and short positions and will itself be either long or short. ${ }^{7}$ Currency option combinations can be used both to hedge cash inflows and outflows denominated in a foreign currency and to speculate on the future movement of a foreign currency. More specifically, MNCs or local corporations such as ACI Corporation based on Bangladesh and individual speculators can construct a currency option combination to accommodate expectations of either appreciating or depreciating foreign currencies.

One of the most popular currency option combinations are Currency Straddles. For this combination, the following topics will be discussed:

- The composition of the combination

- The worksheet for the long combination

- The worksheet for the short combination

- Uses of the combination to speculate on the movement of a foreign currency.

\subsubsection{Hedging with Long Currency Straddles}

When constructing a long straddle, the buyer purchases both the right to buy the foreign currency and the right to sell the foreign currency. Since the call option will become profitable if the foreign currency appreciates, and the put option will become profitable if the foreign currency depreciates, a long straddle becomes profitable when the foreign currency either appreciates or depreciates. Obviously, this is a huge advantage for the individual or entity that constructs a long straddle, since it appears that it would benefit from the position as long as the foreign currency exchange rate does not remain constant. The disadvantage of a long straddle position is that it is expensive to construct, because it involves the purchase of two separate options, each of which requires payment of the option premium. Therefore, a long straddle becomes profitable only if the foreign currency appreciates or depreciates substantially.

Worksheet for Long currency straddles:

To determine the profit or loss associated with a long straddle (or any combination), it is easiest to first construct a profit or loss worksheet for several possible currency values at option expiration. The worksheet can be set up to show each individual option position and the net position.

Put and call options are available for euros $(€)$ with the following information:

- Call option premium on euro $=$ BDT.03 per unit.

- Put option premium on euro =BDT.02 per unit.

- Strike price = BDT1.05.

- One option contract represents $€ 62,500$.

To construct a long straddle, the buyer (say for ACI

7 Jorion, P., 1990, "The Exchange Rate Exposure of U. S. Multinationals," Journal of Business (July), 331-345. 
corporation) would purchase both a euro call and a euro put option, paying BDT.03+ BDT.02= BDT.05 per unit. If the value of the euro at option expiration is above the strike price of BDT1.05, the call option is in the money, but the put option is out of the money. Conversely, if the value of the euro at option expiration is below BDT1.05, the put option is in the money, but the call option is out of the money. A possible worksheet for the long straddle that illustrates the profitability of the individual components is shown below:

Table 9. Value of Euro at option expiration.

\begin{tabular}{|c|c|c|c|c|c|c|}
\hline \multicolumn{7}{|c|}{ Value of Euro at option expiration } \\
\hline & BDT0.95 & BDT1.00 & BDT1.05 & BDT1.10 & BDT1.15 & BDT1.20 \\
\hline $\begin{array}{l}\text { Own a } \\
\text { call }\end{array}$ & -BDT0.03 & -BDT.03 & -BDT.03 & +BDT.02 & +BDT.07 & +BDT.12 \\
\hline $\begin{array}{l}\text { Own a } \\
\text { put }\end{array}$ & +BDT.08 & +BDT.03 & -BDT.02 & -BDT.02 & -BDT.02 & -BDT.02 \\
\hline Net & +BDT.05 & BDT.00 & -BDT.05 & BDT0.00 & +BDT.05 & +BDT.10 \\
\hline
\end{tabular}

Source: Report of Treasury department in ACI

In above table, there are two break-even points for a long straddle position - one below the strike price and one above the strike price. The lower break-even point is equal to the strike price less both premiums; the higher break-even point is equal to the strike price plus both premiums. Thus, for the above example, the two break-even points are located at BDT $1.00=$ BDT $1.05-$ BDT.05 and at BDT $1.10=$ BDT $1.05+$ BDT 0.05 . The maximum loss for the long straddle in the example occurs at a euro value at option expiration equal to the strike price, when both options are at the money. At that point the straddle buyer, ACI incorporation, would lose both option premiums. The maximum loss for the straddle buyer is thus equal to BDT $0.05+$ BDT $0.03=\mathrm{BDT} 0.02$.

\subsubsection{Hedging with Short Currency Straddles}

Constructing a short straddle in a foreign currency involves selling (taking a short position in) both a call option and a put option for that currency. ${ }^{8}$ As in a long straddle, the call and put option have the same expiration date and strike price. The advantage of a short straddle is that it provides the option writer with income from two separate options. The disadvantage is the possibility of substantial losses if the underlying currency moves substantially away from the strike price.

Worksheet for Short currency straddles:

A short straddle results in a worksheet and contingency graph that are exactly opposite to those of a long straddle as illustrated below:

Assuming the same information as in the previous example, a short straddle would involve writing both a call option on euros and a put option on euros. A possible worksheet for the resulting short straddle is shown below:

The worksheet also illustrates that there are two break-

8 Bodnar, G., Hayt, G., Marston, R., and Smithson, W., 1995, IWharton survey of derivatives usage by U. S. non-financial firms." Financial Management, 24, Summer. even points for a short straddle position-one below the strike price and one above the strike price. The lower break-even point is equal to the strike price less both premiums; the higher break-even point is equal to the strike price plus both premiums. Thus, the two break-even points are located at BDT $1.00=$ BDT1.05 - BDT.05 and at BDT1.10 = BDT1.05+BDT.05. This is the same relationship as for the long straddle position. The maximum gain occurs at a euro value at option expiration equal to the strike price of BDT 1.05 and is equal to the sum of the two option premiums (BDT.03+BDT.02=BDT.05).

Table 10. Value of Euro at option expiration.

\begin{tabular}{|c|c|c|c|c|c|c|}
\hline & BDT0.95 & BDT1.00 & BDT1.05 & BDT1.10 & BDT1.15 & BDT1.20 \\
\hline $\begin{array}{l}\text { Sells a } \\
\text { call }\end{array}$ & +BDT0.03 & +BDT.03 & $+\mathrm{BD}$ & -BDT.02 & -BDT.07 & Г.12 \\
\hline $\begin{array}{l}\text { Sells a } \\
\text { put }\end{array}$ & -BDT.08 & $-B D$ & +BDT.02 & +BDT.02 & +BDT.02 & Т.02 \\
\hline Net & -BDT.05 & BDT.00 & +BDT.05 & ВDT0.00 & -BDT.05 & -BDT.10 \\
\hline
\end{tabular}

Source: Report of Treasury department in ACI

\subsubsection{Speculating with Currency Straddles}

Firms in Bangladesh can also speculate using currency straddles based on their expectations of the future movement in a particular foreign currency. For example, speculators who expect that the British pound will appreciate or depreciate substantially can buy a straddle. If the pound appreciates substantially, the speculator will let the put option expire and exercise the call option. If the pound depreciates substantially, the speculator will let the call option expire and exercise the put option. To illustrate the situation, consider the following example of speculating with currency straddles.

Call and put option contracts on British pounds (£) are available with the following information:

- Call option premium on British pounds = BDT.035.

- Put option premium on British pounds = BDT.025.

- Strike price = BDT1.50.

- One option contract represents $£ 31,250$.

At expiration, the spot rate of the pound is BDT1.40. A speculator who had bought a straddle will therefore exercise the put option but let the call option expire. Therefore, the speculator will buy pounds at the prevailing spot rate and sell them for the exercise price. Given this information, the net profit to the straddle buyer is calculated as follows:

Table 11. The net profit to the straddle buyer.

\begin{tabular}{|c|c|c|}
\hline Descriptions & per unit & per contract \\
\hline Selling price of $£$ & +BDT1.50 & $\begin{array}{l}\text { BDT46,875 (BDT } 1.50 \times 31,250 \\
\text { units) }\end{array}$ \\
\hline (-)Purchase price of $£$ & -1.40 & $-43,750$ (BDT1.40 x 31,250 units) \\
\hline $\begin{array}{l}\text { (-)Premium paid for } \\
\text { call option }\end{array}$ & -0.035 & -1,093 (BDT.035 x 31,250 units) \\
\hline $\begin{array}{l}\text { (-)Premium paid for } \\
\text { Put option }\end{array}$ & -0.025 & -781.25(BDT.025 x 31,250 units) \\
\hline$=$ Net profit & +BDT0.04 & +1,250 (+BDT.04x 31,250 units) \\
\hline
\end{tabular}

Source: Report of Treasury department in ACI 
The straddle writer will have to purchase pounds for the exercise price. Assuming the speculator immediately sells the acquired pounds at the prevailing spot rate, the net profit to the straddle writer will be:

Table 12. Net profit to the straddle writer.

\begin{tabular}{|c|c|c|}
\hline Descriptions & per unit & per contract \\
\hline Selling price of $£$ & +1.40 & $\begin{array}{l}+43,750 \text { (BDT } 1.40 x \\
31,250 \text { units) }\end{array}$ \\
\hline (-) Purchase price of $£$ & -BDT1.50 & $\begin{array}{l}\text {-BDT46,875 (BDT1.50 x } \\
31,250 \text { units) }\end{array}$ \\
\hline $\begin{array}{l}(+) \text { Premium received for call } \\
\text { option }\end{array}$ & +0.035 & $\begin{array}{l}+1,093 \text { (BDT.035 x 31,250 } \\
\text { units) }\end{array}$ \\
\hline $\begin{array}{l}(+) \text { Premium received for Put } \\
\text { option }\end{array}$ & +0.025 & $\begin{array}{l}+781.25 \text { (BDT. } 025 \times 31,250 \\
\text { units) }\end{array}$ \\
\hline$=$ Net profit & -BDT0.04 & $\begin{array}{l}-1,250(+B D T .04 \times 31,250 \\
\text { units })\end{array}$ \\
\hline
\end{tabular}

Source: Report of Treasury department in ACI

As with an individual short put position, the seller of the straddle could simply refrain from selling the pounds (after being forced to buy them at the exercise price of BDT1.50) until the spot rate of the pound rises. However, there is no guarantee that the pound will appreciate in the near future.

\section{Findings}

Followings are the generalized statements after analyzing the above scenario in order to render a conclusive output for this study:

a) After analyzing the foreign exchange exposures of ACI Incorporation of Bangladesh, We have found that the cross-sectional variation in exchange risk sensitivity of individual firms is related to firm-specific operational variables.

b) We find that at the country level like Bangladesh, the extent of exposure is robust, although which firms such as ACI or General Motors engaged in currency hedging are affected by movements in the exchange rate and the direction of exposure depends on the specific exchange rate and varies over time.

c) Our estimations revealed a transparent relationship between the scope of the foreign operations of a firm such as ACI corporation-measured by foreign sales, assets, and operating profits - and its exchange risk sensitivity.

d) In addition, it's also derived from the above analysis that the use of currency derivative to hedge currency risk is not so popular among the firms (except ACI \& General Motors) existing in Bangladesh due to its complexity related to the expectation of future exchange rates between Bangladesh and other foreign countries.

e) Another information which is also crucial regarding this paper is that the use of Options contract a significant part of currency Hedging can also be used as Range Derivative contract by the firms practicing currency hedging in Bangladesh such as ACI or
General Motors because options contract provides a range of rates for exchanging the currencies consisting of in the money, on the money and out of the money.

f) Future studies that include additional operational and managerial information collected from survey data should provide further insights into the complex relationship between exchange rate fluctuations and firm value.

\section{Conclusions}

In summary, we have found a significant nexus between the use of foreign currency derivative to hedge currency risk and firm exchange-rate exposure, suggesting that firms use derivatives as a hedge rather than to speculate in the foreign exchange markets of Bangladesh. In this paper we examined exchange risk exposures at the company level by only one Industry named as ACI based on Bangladesh engaged in currency hedging operations to mitigate foreign exchange exposures, we found limited support for the importance of the exchange rate factor. This may be explained by the fact that although firms in a given industry are in the same primary line of business, they are still heterogeneous in terms of their operational and financial characteristics. Since industry groups include firms with positive and negative exchange risk exposure, aggregating across such firms will result in finding an insignificant exposure coefficient for the industry group. We also postulate that exchange rate exposure may be linked to a number of firm- and industry-level characteristics. Our analysis of exposure suggests both that exchange rates have measurable effects on firms, and that firms adjust their behavior in response to exchange rate risk. Further, our results suggest that estimates of exchange rate exposure using industry-level data, or specific subsamples of firms that are "most likely" to be exposed, may well be biased downward, in that exposure seems not to be concentrated in specific industries and firms that are most susceptible to exposure are likely to actively hedge those risks. Firms existing in Bangladesh can also use foreign debt to protect themselves from exchange-rate movements. Similarly, we find that a firm's exposure (illustrated as ACI's exposures in this paper) through foreign sales is an important determinant of its decision to hedge and how much to hedge. Collectively, our results suggest that any corporation of Bangladesh uses currency derivatives and foreign debt as a hedge against their exchange-rate exposure. Our paper has important implications for managers and financial regulators. It should be always remembered by the managers especially the treasury managers of Bangladeshi firms that a firm's exposure to exchange-rate movements is mitigated through the use of foreign currency derivatives. This finding suggests that an intervention in the derivatives markets may not be warranted, and provides an explanation for the lack of significant exposure documented in past studies. 


\section{References}

[1] Allayannis, G., 1996, \ Exchange rate exposure revisited, Working Paper, Darden Graduate School of Business, University of Virginia.

[2] Bodnar, G., Hayt, G., Marston, R., and Smithson, W., 1995, Wharton survey of derivatives usage by U. S. non-financial firms. Financial Management, 24, Summer.

[3] Block, S. and Gallagher, T., 1986, \ The use of interest rate futures and options by corporate financial managers" Financial Management, Autumn.

[4] Booth, J., Smith, R., and Stolz, R., 1984, \The use of interest rate futures by financial institutions Journal of Bank Research, Spring.

[5] Corporate Annual Reports and reports of treasury department at ACI (Advanced Chemical Industries Ltd.) from 2005 to 2010 .

[6] Froot, K., Scharfstein, D., and Stein, J., 1993, \Risk management: Coordinating corporate investment and financing policieses, Journal of Finance.

[7] Hamada, R. S., 1972, "The Effect of Firm's Capital Structure on the Systematic Risk of Common Stock," Journal of Finance (June), 435-452.

[8] Hodder, J. E., 1982, "Exposure to Exchange - Rate Movements," Journal of international Economics (November), 375-386.

[9] Haushalter, D., 1997 । The role of corporate hedging: Evidence from oil and gas producers Working Paper, Purdue University, West Lafayette, IN.

[10] Hodder, J., 1982, \ Exposure to exchange rate movements, Journal of International Economics, 13, November.

[11] Jorion, P., 1990, "The Exchange Rate Exposure of U. S. Multinationals," Journal of Business (July), 331-345.

[12] Shapiro, A., 1975, \Exchange rate change, inflaation and the value of the multinational corporation, Journal of Finance, 60.

[13] Simkins, B., and Laux, P., 1997, \Derivatives use and the exchange rate risk of investing in large U. S. corporations, Working Paper, Case Western Reserve University.

[14] Stulz, R., 1984, \ Optimal hedging policies, Journal of Financial and Quantitative Analysis 19, June. 